\title{
Religious Celebrity: The Metamorphosis of Islamic Preachers in Indonesia
}

\author{
Iim Halimat usa'diyah \\ Lecturer of Social and Political Science Faculty (FISIP) \\ UIN Syarif Hidayatullah Jakarta \\ iim_hs@yahoo.com
}

\begin{abstract}
Abstrak
Artikel ini mendiskusikan secara kritis transformasi para pendakwah Islam popular di Indonesia menjadi selebritis agama (religious celebrity). Salah satu penjelasan yang coba dikemukakan di sini adalah bahwa fenomena selebritisasi da'i (Islamic preacher) tersebut merupakan hasil langsung dari meningkatnya penggunaan teknologi media sebagai alat baru dalam mendiseminasikan diskursus keislaman. Melalui dukungan teknologi media massa, para pendakwah Islam kontemporer dapat dengan mudah memperoleh audiens yang luas, dan secara bersamaan memperoleh pengakuan publik. Namun pembacaan terhadap transformasi para da'i menjadi selebritis agama ini, setidaknya, menemukan dua poin penting terkait eksploitasi media. Pertama, kemampuan orang mengeksploitasi media sebagai alat untuk menyebarkan diskursus keagamaan. Kedua, media dapat juga mengeksploitasi agama dengan menjadikannya komoditas untuk memperoleh keuntungan yang lebih besar.
\end{abstract}

\begin{abstract}
The article critically discusses the transformation of popular Islamic preachers in Indonesia into religious celebrity. One of the explanations is that the phenomenon of this transformation is a direct result of the increasing using of media technology as a new tool in the dissemination of Islamic discourse. Through the support of mass media technology, these contemporary Islamic preachers are easily obtained a wide audience and simultaneously obtained a public recognition. This article, at least, found two important points related to the exploitation of the media. First, people are able to exploit the media as a tool to disseminate religious discourse. Second, the media can also exploit religion by making it as commodities to gain a greater advantage.
\end{abstract}

Keywords: media, Islamic preacher ( $\left.d a^{\prime} i\right)$, technology, religion 


\section{Introduction}

As a major religion in Indonesia, Islam constitutes more than 80 percent of the Indonesian population. Therefore it is not surprising that every aspect of life in Indonesia is closely related to Islam. Tracing back to the early phase of Islam in Indonesia, the role of ulama or kiyai, the Islamic religious scholar, in the development of Islam in Indonesia cannot be just passed over. Historically speaking, the first dissemination of Islam in Java, for instance, cannot be separated from the role of Wali Songo, the nine saints. They are still popularly remembered as legendary figures among Javanese and Indonesian Muslims for their merit in peacefully and culturally spreading Islam widely throughout Java. Considering the pivotal role of ulama or kiyai in Indonesian Islam, they, at the same time, gain more respect from society since they are role models for society. To some extent the ulama function as the Prophet's surrogate; they are therefore people to ask and consult about their religious problems. Therefore, there are certain high standards required to be an ulama, particularly in terms of religious knowledge.

Another term that has an inextricable relationship with the ulama and kyai is da'i (Islamic preacher). Since the notion of dakwah, religious proselytizing, is pivotal in Islam, preaching is then one way to implement it. Similarly with ulama or kiyai, da'i can also gain respect and popularity from society. For decades, every Islamic preacher in Indonesia has been an ulama or kyai or at least they are (still the genealogy) of the traditional families of ulama. Today, with the advance of media technology, someone can easily gain popularity as an Islamic preacher. This paper therefore will critically discuss and explore the transformation of religious celebrity in Indonesia with a closer look at the rise of new media technology in Islamic preaching.

\section{Media and New Religious Public Sphere}

Daniel Boorstin's book, The Image: A Guide to Pseudo-Events in America, ${ }^{1}$ has apparently made a significant contribution to the way we identify the differences between fame in recent years and in the previous era. The rise of celebrity culture cannot be detached from what Boorstin called "Graphic Revolution". He mentions that the invention of media technology, which has resulted in mass publications and communications flourishing, has shifted the notion of fame that previous generations had. He then firmly states that before the revolution in communication technology, it was on account of their "greatness", such as social status, heroic deeds or life achievement, that

\footnotetext{
${ }^{1}$ This book was published by Vintage Books, New York, in 1992. See Daniel Boorstin, The Image: A Guide to Pseudo-Events in America (New York: Vintage Books, 1992).
} 
people were considered as famous. What makes people famous nowadays or since the emergence of this revolution is no longer based on their heroic achievements or the greatness they have, but more on their "well-knowness". The advance of media communication has shifted the idea of public spheres in which every single thing in our everyday life can be consumed in the public domain. Therefore it is now easy for people to be well-known as long as the public is already familiar with their life. Moreover, as a result of the expansion of this communication technology, fame has more recently become attached to various other professions. It does not solely belong to stars, but also to musicians, politicians, athletes and prominent religious figures.

The innovation of the media technology that initially emerged in the late nineteenth and early twentieth century in European countries nowadays has spread globally all around the world including into Muslim worlds. As a consequence, mass communication has shifted the notion of the new public sphere. As Eickelman and Anderson (2003, first edition 1999) mention, the revolution of mass communication technologies has led to the revolution of religious thinking in every Muslim country. The authoritative use of Islamic symbols nowadays is significantly more open and global. ${ }^{2}$

Additionally, the authoritative interpretations of Islam that had been well preserved in ulama's hands are now in multiple hands. In fact, people who have little or no formal training in Islamic Jurisprudence ( fiqh) or other specialties of the conventionally trained ulama can produce Islamic interpretation. ${ }^{3}$ Therefore, it is not surprising that people now can easily gain access to Islamic knowledge without solely relying on ulama. They can find it from other sources such as video tapes, books, pamphlets, and internet, TV and radio programs and in every marketplace. This state of affairs has significantly challenged the authority of ulama.

Although in some places, TV and radio broadcasting are not absolutely free. The global expansion of mass media communication cannot easily be prevented. Even many religious figures now take benefit from modern media communications to deliver and disseminate their preaching and dakwah. Thus, they can easily gain more popularity in society. In relation to this transformation, the popularity of previous ulama has also been contested with the emergence of many new religious celebrities in the Muslim world.

Indonesia as one of the biggest Muslim countries also encountered the expansion of mass communication technology. From the late 1960s, people in

${ }^{2}$ Dale Eickelman and Jon Anderson, eds., New Media in the Muslim World: The Emerging Public Sphere, $2^{\text {nd }}$ ed. (Bloomington: Indiana University Press, 2003), 1.

${ }^{3}$ Eickelman and Anderson, New Media in the Muslim World, 21. 
Indonesia could have access to television. Although it was still centralized in Jakarta, people in villages could also enjoy television as a result of new satellite technology, since Indonesia was the third country in the world to launch its own communication satellite, namely Palapa satellite. Not only was TV used to disseminate popular music and TV series, but also it was used as a propaganda medium for the state. Additionally, TV gave the opportunity for religious broadcasts and for religious figures that were only locally well-known, to become more nationally recognized. Besides TV, cassette technology, books and pamphlets also became effective media for distributing religious sermons since these forms of homilies were always available in every market all over Indonesia and became topics of public discussion. ${ }^{4}$

Some earlier Islamic preachers in Indonesia had already made good use of mass media technology to become popular national religious figures. Hamka, for instance, was the first person who benefited from this technology. He was originally from Kampung Molek in West Sumatra an Indonesian province. His father was well known as the pioneer of the ishlah (modernism) movement after his return from Makkah in 1906. Hamka later on was called Buya, which is rooted from the Arabic word abi, abuya that means "my father". In Sumatran tradition, it is used to call someone respected.

On account of his deep religious knowledge, Hamka had been chosen as the first general chairman of the Indonesian Council of Ulama(MUI), and held this position from 1975-1981. MUI is an institution that functions to issue Islamic legal opinion (fatwa) in Indonesia. Additionally, from the 1950's, Hamka had become nationally well known as a politician since he was actively engaged in one of the biggest Islamic political parties in the era of Sukarno (the first president of Indonesia), namely Masyumi. ${ }^{5}$ Besides being a religious and political figure, Hamka was also well known as a writer, editor and publisher. He was a journalist since the1920's. He had also produced some Islamic scientific books and some romantic novels. Because of television broadcasts, the publication of religious magazines, and the distribution of religious cassettes and Hamka's books, from the 1970's, Hamka's popularity was not only in his own local community and in Indonesia, but also in neighboring countries such as Malaysia and Singapore. ${ }^{6}$ Since his death in 1981 until the present day people still remember who Hamka was.

\footnotetext{
${ }^{4}$ C.W. Watson, “A Popular Preacher: The Significance of Aa Gymnastiar,” Journal of Royal Anthropological Institute, (NS) 1 (2005): 782.

${ }^{5}$ Abbreviation of Masyarakat Umat Islam Indonesia (Indonesian Muslim Society).

${ }^{6}$ Dasman Djamaluddin, "Mengenang Sastrawan Besar Hamka,"

http://buyahamka.org/bagian-sebelum-tafsir/mengenang-sastrawan-besar-hamka/ (accessed November 14, 2012).
} 
Another Islamic Preacher who took advantage from the expansion of media technology is Zainuddin MZ. He was popular as an Islamic preacher because his preaching style was uncomplicated and attractive to many people from different social- cultural backgrounds, particularly for rural audiences. Therefore, since his preaching was always attended by thousands of people, he was then called "Da'i Sejuta Umat" (thousands of people's preacher).

He gained more popularity as an Islamic preacher because his preaching utilized the recording industry. His cassettes of sermons were not only widespread all over Indonesia, but also in other Asian countries. From then on his face always appeared on certain TV programs. He received a contract from one of the TV stations to travel to many regions in Indonesia to deliver his preaching in collaboration with some popular singers under the program of "Nada dan Dakwah" (song and dakwah). Similarly with Hamka, Zainuddin was also known as a politician and was active in the United Development Party (Partai Persatuan Pembangunan), the only state Islamic party in the Suharto regime. He was at the peak of his career during this period.

It is true that both these religious figures gained benefits from media technology in expanding their popularity. However, as religious figures they had talent and achievements that could meet the traditional requirements of being ulama or kiyai or da'i. Both are considered as having good understanding of Islam since they had comprehensive Islamic educational backgrounds, either in their institutional education or in their family and environmental education. Hamka's father, for example, was a prominent religious figure in Sumatra. Therefore, his religious knowledge was automatically passed down to Hamka. In Indonesian tradition, it is natural that when the father is an ulama or kiyai, that the son will be educated and trained to be ulama or kiyai as well, so as to continue the family's tradition. Society then will not hesitate to accept their Islamic understanding considering their Islamic knowledge and their family backgrounds. People automatically will respect them and at the same time ulama or kiyai will gain fame among their society and occupy a respected social status. As Geertz points out, the classical role of kiyai is to be a cultural broker in which he is "a specialist in the communication of Islam to the mass." $\mathrm{He}$ therefore occupied the pivotal position in the social structure of community. ${ }^{8}$

Looking closer at the role of media in the case of Hamka, it can be seen that he was already a great person in his society before finally becoming more

\footnotetext{
${ }^{7}$ Encyclopedia of Indonesian Figures, “KH. Zainuddin MZ: Da'i of Reformation Star," Tokoh Indonesia DotCom, posted on April 4, 2004, http.//www.tokohindonesia.com/majalah/09/zainuddin.html (accessed December 10, 2006).

${ }^{8}$ Clifford Geertz, "The Javanese Kijaji: the Changing Role of a Cultural Broker," Comparative Studies in Society and History 2 (1960): 230.
} 
well known. What the media did was only to disseminate his greatness to broader society. It is not the media which made him a great man. As Boorst ain has attempted to clarify- it is possible to create a well known person but not a great person. In short, Hamka was a great man because of his talents and the achievements he had made, while at the same time he became a well known person having benefited from the media expansion in Indonesia. ${ }^{9}$

However, as an ulama, Hamka emphasized more dogmatic religious teachings and since Indonesian religiosity has changed to be more spiritualistic rather than dogmatic, it makes his dogmatic appeals less popular for recent generations. Zainuddin on the other hand was able to offer a more attractive kind of preaching compared to Hamka's. He gained more benefits from the expansion of mass media technology which widely publicized his preaching style. He is considered as having a different preaching style compared to Hamka.

Recently, the advance of new media technology has shifted into a new religious public sphere. This new technology has brought people about to be more involved in producing and maintaining a religious public sphere in which religious authority is fragmented and more publicly open. It is no longer solely in the ulama's hand that Islamic discourses are produced and sustained. Consequently, this new advanced media technology has created the emergence of new people in the construction of Islamic discourses. Additionally, these discourses are produced in more advanced and various forms. Therefore, this state of affairs has led to religious issues becoming more similar with commerce, entertainment, and the professions. At the same time, this condition has opened up broader opportunity for the rise of religious celebrity. Religious figures have already been transformed from their traditional role as religious sources for people to rely on, to cultural icons or to celebrity personalities since the shaping of a new public sphere is considered more on those who appear on national television, publish mass-circulation books and newspapers. ${ }^{10}$ Religious figures then can be manufactured to be more of a religious celebrity and juxtaposed with other kinds of celebrity.

\section{New Generation of $\mathrm{Da}^{\prime} \mathbf{i}$}

Considering the emergence of a new religious public sphere in Indonesia, there are some new preachers that have emerged as popular Islamic preachers like the two preachers previously mentioned. One of them is Abdullah

\footnotetext{
${ }^{9}$ D.J. Boorstain, The Image: A Guide to Pseudo-events in America (New York, USA: Vintage Books, 1992), 48.

${ }^{10}$ Dale Eickelman and Jon Anderson, eds., New Media in the Muslim World: The Emerging Public Sphere, $2^{\text {nd }}$ ed, 14.
} 
Gymnastiar who is popularly called Aa Gym. He has introduced a new concept to Islamic dakwah namely Managemen Qolbu (MQ). This concept tries to appeal to people to understand their heart ( $q o l b u$ ) and inner feelings so as to be able to control themselves, since he believes that our self is the root of everything that happens to us.

His approach does not emphasize dogmatic Islamic teaching but is trying to give a new understanding of the importance of Islam in the reality of everyday life that it in turn is expected to solve either domestic or professional problems people encounter. Aa Gym always combines his very simple moral advice with direct practical teaching of good management practice. ${ }^{11}$ His approach to Islam has attracted many people from all different backgrounds: head of state and ministers, middle class, common people, even those who are from other religious backgrounds. With regard to his approach, he is considered as a new alternative of modern and moderate Muslim. As Juniwati Masjchun Sofwan, a member of MUI (the Council of Indonesian Ulamas) believes, the success of Aa Gym is rooted in his teachings that urge "a very human nature of Islam and practices." 12 On account of the popularity of his charismatic personality, Time magazine has proclaimed him as an Indonesian holy man. ${ }^{13}$

As with the other two aforementioned preachers, Aa Gym was originally a local figure from Bandung, West Java. What makes him different from his two predecessors is that the advanced development of communication during this period of time significantly transformed local figures like Aa Gym, and they were able to achieve national reputations in a very short period of time with wider audiences. The success of his exploitation of media technology is of course closely related to the political situation in Indonesia at the time he first established his career. The fall of Suharto's regime in 1998 had broken up the very authoritative controls of every aspect of life in Indonesia. This consequently brought about wider opportunity for mass communications to flourish, and for many political and religious expressions to emerge. It could be said that Aa Gym first emerged because he was able to strategically make very good use of mass media technology at a time when the press were experiencing new found freedoms. This is indicated by the emergence of many new TV stations and new print media, some of whom had previously been banned. Thus, the new religious expression that he was trying to introduce more easily received a positive response from the Muslim community.

\footnotetext{
${ }^{11}$ C.W. Watson, “A Popular Preacher: The Significance of Aa Gymnastiar,” Journal of Royal Anthropological Institute, (NS) 1 (2005): 788.

${ }^{12}$ Time 04 November 2002.

${ }^{13}$ Time 11 November 2002.
} 
With his entrepreneurial skills, Aa Gym knew best how to benefit from modern technological developments. At his local residence, he built a religious complex called Daarut Tauhid(DT). The very basic notion behind this complex was to combine the religious center, (consisting of a pesantren (religious school) and mosque as proliferation of the cultural institution that traditional kiyai commonly have) and the entrepreneurial home base, in which he has a foundation called Managemen Qolbu (MQ) which runs the enterprise and produces diverse commercial ventures. Through this foundation, he owns a home production studio which broadcasts and publishes his sermons and his works, which in turn are distributed to the public through television, cassettes, CDs, videos, and the print media. In short, he utilizes these mass media tools to expand his appeal to the broader Muslim community. Consequently, the rise of his popularity is signified by his frequent appearance in newspapers, magazines, and on television screens, and his visibility on many DVDs, videos, and on the covers of many books and pamphlets about his works and works about him. As for his availability in the media, Watson describes him as having "a masterful command of the media."14

Additionally, the Daarut Tauhid has, opened up economic opportunity for the surrounding community, since many people from all over Indonesia visit this complex to directly see and listen to Aa Gym's sermons. These visits are well known as wisata rohani (spiritual tourism). Concerning his entrepreneurial talents, Time magazine describes him as "Indonesia's hottest Muslim preacher", a slick mix of piety and prosperity" since he pays more attention to improving Muslims economically through modern-day practices of business and religion. ${ }^{15}$ His entrepreneurial talents have made him different from the two previous preachers, and it is therefore not surprising that he has gained popularity faster than the other two forerunners.

Aa Gym's success in attracting people from all social strata of course has resulted in different responses from many Indonesian Muslim scholars. Some approve of his ability to convey new dimensions of practical spirituality and fundamental morality and piety towards many people from various sociocultural backgrounds. Others however are hesitant that his standards of religious knowledge are lacking since he has not graduated from one of the major religious schools (pesantren) in Indonesia as his forerunners had. Therefore, his Sufism thought is not based on orthodox Muslim education, but mostly relies on secular sources from Sufi texts. He therefore does not possess Arabic knowledge and expertise of the Islamic classical texts. Moreover, he

\footnotetext{
${ }^{14}$ C.W. Watson, “A Popular Preacher: The Significance of Aa Gymnastiar”. 773.

${ }^{15}$ Time 11 November 2002.
} 
does not belong to a religious scholar's family, which the traditional kiyai usually come from. ${ }^{16}$

Another suspicious argument/suspicion/criticism to emerge is that his achievement is mainly based on his capability in exploiting the mass media. He exists and has become a huge figure only because of the media support he has. As a consequence of this he can be juxtaposed with other forms of celebrities that instantly gain popularity, then quickly decline and disappear, replaced by new religious celebrities.

Another of the new generation of preachers that is currently at the peak of his popularity is Jeffry Al Buchory. Compared to Aa Gym, who established his career in 1998, Jeffry, who prefers to be called an ustadz (teacher) rather than Kiyai or ulama, has gained popularity since his first appearance on television in 2002. Therefore, his name is not as popular as Aa Gym. While Aa Gym's audiences are from various social backgrounds and ages, Jeffry's audiences are mostly young people or teenagers. His younger age means he doesn't yet have appeal with adult audience. He says that what he does is not preaching, but it is only discussion or sharing, since, he points out, he is still studying how to preach. ${ }^{17}$ In considering his audience, Jeffry employs methods that are readily accepted by younger generations. It is not surprising that in his preaching he uses some slang words that the younger generations commonly use, since he believes that thinking in the way the teens think is the best way to understand them. His familiarity with teenagers makes him well known as "ustadz gaul" (funky preacher), and his popular nickname is Uje, the abbreviation of Ustadz Jeffry.

Besides the aforesaid differences between Aa and Jeffry, both are similar in terms of the media's role in their popularity. Both use the media as a way to disseminate their Islamic discourses and it is through the media that they have become well known amongst their audiences. Jeffry even admitted that television has made him famous and well known to many people. He therefore does not hesitate to utilize this media technology as his dakwah medium since he believes it can be used for something good such as disseminating Islamic appeal. Besides preaching he also produces albums and acts in advertisements because dakwah can be done not only through preaching but can be in other forms which he can attach Islamic values to. Still, some people disagree with what he has done. It would seem to them that he uses media to escalate his own popularity as a celebrity. Jeffry realizes that popularity is an inevitable

\footnotetext{
${ }^{16}$ C.W. Watson, “A Popular Preacher,” Journal of Royal Anthropological Institute, 784.

${ }^{17}$ Liputan6.com, "Jeffry al-Bukhori prefers to be called as Ustadz," Liputan6.com, 03 November, http://www.liputan6.com/view (accessed October 9, 2006).
} 
consequence of his attachment to television. To refute this suspicion he says that he is familiar with the media industry because he was a celebrity beforehand. He did not feel happy being celebrity as it only led him to a dark life and made him a drug addict. Learning from his dark experiences before being a preacher, he is absolutely certain that what he does through the media's assistance is not for gaining celebrity popularity. ${ }^{18}$

Another similarity between Aa and Uje is that both have an institution as a center for their dakwah. While Aa already has a well established Daarut Tauhid Pesantren, Uje has Majlism Mim that is still in an ongoing process of establishment as it is still located in Uje's home. In this Majlism Mim, Uje delivers weekly pengajian (Islamic sermons and discussions). ${ }^{19}$

It can be seen that the existence of Islamic institutions (pesantren) which are owned and run as dakwah centers is something that still exists and is intentionally preserved from generation to generation. The existence of their pesantren has placed the preachers in the same position as previous kiyai - they still have the same function as "cultural brokers", to mediate for local people and the broader society. They still hold positions of respect and many people will take into consideration what they communicate. ${ }^{20}$

In line with this point, it can be concluded that what makes a difference between the recent and the previous generations of preachers is only a matter of degree and quantity. It is on account of the development of media technology that the possibility to communicate in a more public sphere has become more widely available. Therefore, the later generations of preacher can more easily gain greater public attention when compared with their predecessors.

Another point of dissimilarity is that, while the previous preachers tended to employ the straightforward restriction of Islamic teachings to their preaching, the recent generation is likely to adopt ways that are easily accepted by their audiences. Aa Gym, for instance, uses daily analogy and humor in his preaching, while Jeffry additionally uses popular or slang words that teenagers commonly use. They believe that the concept of dakwah should be simplified. However, it does not mean that their topics of preaching are not important, it is only their way of making the difficult issues more easily understood and accepted by their audiences.

\footnotetext{
${ }^{18}$ Liputan6.com, “Jeffry al-Bukhori,” Liputan6.com.

${ }^{19}$ Gatra.com 24 October 2005.

${ }^{20}$ Clifford Geertz, "The Javanese Kijaji," Comparative Studies.
} 


\section{Preachers of the Television Generation}

The new way of preaching that focuses more on the audiences satisfaction has attracted many television producers wanting to take advantage of it by creating TV programs that basically combine preaching with entertainment. The dakwah programs on television are modified in a more attractive way since dakwah using popular words and humour tends to receive lots of interests from the public. As one of the producers of these programs points out, the purpose of these programs is to show to the public the preacher who can deliver religious teachings in a fun and relaxed manner. ${ }^{21}$ As a result of these programs many new preachers have emerged on TV in collaboration with comedians, singers, actors, actresses, etc. On one of these TV stations, there is even a da' $i$ competition program to find a new preacher. This program is similarly designed the same as other recent competition programs to choose a new singer, new model, new dancer, etc. This kind of program has boomed in many parts of the world, for instance; X factor in the UK, American Idol, Indonesian Idol, Malaysian Idol and many other idol programs in other parts of the world. These preachers, to some extent, can be considered as having the same status as the entertainers that accompany them. They are religious celebrities that have emerged and become well known on account of media fabrication. Thus they can be considered as "the preachers of the television generation."

This situation is like a double-edged sword. It can be considered as helping to disseminate religious discourses to wider society and in more attractive ways that the audience can easily accept. Additionally, it could be positively responded to since it can be considered as one particular form of Indonesian's religious enthusiasm. However, this situation should also be wisely criticized since it seems that these programs tend to place the emphasis on the entertainment rather than the religious discourse itself. These programs therefore invite many criticisms from many religious scholars.

Quraish Shihab, as a senior religious scholar whose television program Tafsir al-Misbah (Qur'anic exegesis) gains less ratings compared to "these entertaining religious programs", says that he is happy with the emergence of many new young preachers. He also points out that the senior preachers should give opportunities to this younger generation that is in line with this current era and knows better how to deal with the development and the needs of people. However, he also gives notice to these preachers to improve the content of their preaching since he sees too much apportioned to humor rather than religious advice. ${ }^{22}$ Additionally, he believes that the flourishing emergence of

\footnotetext{
${ }^{21}$ Gatra.com 24 October 2005.

${ }^{22}$ Gatra.com 24 October 2005.
} 
the preaching programs that place more emphasis on entertainment and humor is not the fault of the preachers. It is the responsibility of the people behind the television industry as they will not invite preachers that cannot jack up the ratings of their programs. Thus, society has less opportunity to receive religious sermons from university based Islamic scholars since they get less opportunity to appear on television. ${ }^{23}$

Additionally, Didin Hafiduddin, an Islamic scholar who previously appeared on many religious programs on television, is disappointed when the preachers place more emphasis more on entertainment. According to him, a da' $i$ should have a clear line in dakwah, therefore they do not have to follow the market. He also believes that dakwah will lead to positive changes if the da' $i$ can control the market since the role of $d a^{\prime} i$ is to bring about better changes, not to entertain and make people happy. ${ }^{24}$

In line with Didin's argument, Abdul Munir Mulkan, a senior lecturer at one of the State Islamic University in Indonesia, is critical that the quality of dakwah programs on television has significantly decreased because what is important now is how these programs can entertain people, while religious advice is only something inserted. As a result, these programs can dilute the educative values of dakwah itself. The emergence of these entertaining preachers for Munir, is also a critic and a challenge to well established ulama and mass Islamic organizations, such as Nahdlatul Ulama and Muhammadiyah, that they have failed to communicate with their ummah/Muslim community. ${ }^{25}$

It seems that the emergence of these entertaining religious programs is merely being urged on by the commercial values that the television industry can gain. When people feel entertained and like the programs it increases the rating of these programs, and at the same time attracts many companies to advertise their products during these broadcasts. It is emphasized by Smythe that the main function of media is to create stable audiences blocks for sale to monopoly capitalist advertisers, therefore completing the circuit of production can only be achieved by generating the inclination to consume. ${ }^{26}$ Golding and Murdock also define the mass media as "the first and foremost industrial and commercial organizations which produce and distribute commodities within a Late Capitalism economic order." ${ }^{27}$ In short, the religious discourses are exploited for the sake of capitalist benefits since the religious values

\footnotetext{
${ }^{23}$ Gatra.com 24 October 2005.

${ }^{24}$ Gatra.com 24 October 2005.

${ }^{25}$ Gatra.com 24 October 2005.

${ }^{26} \mathrm{D}$. Smythe, The Self-Production of Society (Chicago: University of Chicago, 1977), 1.

${ }^{27}$ Peter Golding \& Graham. Murdock, "Ideology and the Mass Media: The Question of Determination," in Ideology and Cultural Production, ed. Michele Barret, Philip Corrigan, Annette Kuhn, and Janet Wolf (London: Croom Helm, 1979), 210.
} 
themselves cannot be completely planted in people's attitudes. As honestly admitted by Saptomo, the producer of the religious program on RCTI, for the television industry, the first consideration is who will speak on the program rather than what is the topic of discussion. Therefore, they will invite the preacher whom people like. $^{28}$

Therefore, the preachers of the television generation occupy positions of religious celebrity. As with any other kind of celebrities, religious celebrity is also manufactured by a media industry in which they function as what Chris Roject, borrowing from Edgar Morin, termed "entertainment moguls". As entertainers they are the "servant of capital" in which they can be exploited for the sake of capital escalation. ${ }^{29}$ In line with them, Debord (translated by Knabb 2005) has argued that when the commodification of reality, including religious life, takes place, it transform into a spectacle which reduces the authenticity of the reality itself. Additionally, religious figures who occupy the position of religious stars have been the agent of the spectacle, to serve as superficial objects that people can identify with in order to compensate for the fragmented, productive specialization that they actually live. ${ }^{30}$

However, being a religious celebrity is not always signified as something negative, it can also be positive. As a celebrity, religious celebrities also have "transformational power" by which they can guide their audiences to the religious values they are trying to disseminate. ${ }^{31}$ This is likely to be possible since the purpose of the celebrity culture is to drive people into imitative consumption. ${ }^{32}$ Marshall (1997) similarly states that celebrity's power is to represent the active construction of identity in the social world. Religious celebrity therefore can represent the identity of religious figures that people should trust in. Similarly, being a religious celebrity does not destroy the stat us of religious figures as respected persons and role models for the community. Religious celebrity, moreover, escalates the degree of people's belief to follow their role models. Therefore, it is rational that as religious celebrities, their good actions will be an example for the public that in turn will be imitated in people's everyday life. ${ }^{33}$

\footnotetext{
${ }^{28}$ Gatra.com 24 October 2005.

${ }^{29}$ Chris Roject, Celebrity (London: Reaktion Books Ltd, 2001), 34.

${ }^{30}$ Guy Debord, Society of the Spectacle, trans., Ken Knabb (London: Rebel Press, 2005), 29.

${ }^{31}$ Chris Roject, Celebrity, 38.

${ }^{32}$ Chris Roject, Celebrity, 34.

${ }^{33}$ Quoted from M. Newbury, "Celebrity Watching," American Literary History (Oxford: Oxford University Press, 2000), 279.
} 


\section{Conclusion}

Based on the aforementioned descriptions of some popular Islamic preachers in Indonesia, it can be concluded that firstly, the metamorphosis of recent preachers from the previous preachers has been mainly brought about through the advance of media technology as a new tool for disseminating Islamic discourses. At the same time, this media technology has constructed a new form of religious sphere that tends to be more open to the public. Additionally, on account of this media technology, the recent preacher can gain broader audiences since they can more easily be made well-known to the public with this mass media support. However, something to be noted is that it is not only on account of the media that these people become preachers. They basically have the talent to be prospective preachers and what the media does is only spread their preaching skills so they become more widely well-known amongst broader society. At this point, religious figures at the same time occupy a position of religious celebrity. Being a celebrity should not always have a negative association, since, as a religious celebrity, the preacher still can be a role model for society, as were the previous religious figures.

Although having differences from their predecessors, some recent generations of preachers are still preserving the way of their forerunners. Besides taking the benefit from the media in disseminating their appeal, they are still maintaining the traditional structure of pesantren (Islamic institution) that the previous generation had. This institution still has the same function as its forerunners. Its function is as the center of their dakwah that mediate local people to larger society.

Another important point to make is that there are at least two ways of reckoning media-related exploitation. Firstly, there is people's ability to exploit media as tools of disseminating religious discourses. At this point, people know how to control media for religious benefit. Aa Gym is an example of this kind of exploitation. On account of his skillful exploitation of media Aa Gym has achieved national celebrity in extraordinary proportions. On the reverse side, the media can also exploit religion in which the religion is juxtaposed as a commodity that can be utilized to gain more benefits, since it is unlikely that the television industry is fully concerned with Islamic dakwah. Many entertaining religious programs are designed merely to gain lots of money since it cost lots of money to produce these kinds of program. Finally, with the emergence of these "new people" in the Islamic world, it is expected that they know best how to make use of advances in media and, importantly, how to control the media in making positive gains, rather than being used as objects of media exploitation. 


\section{Bibliography}

Bakri, K. B. Sawariyanto and Imung Yuniardi, "Dakwah of Television Generation." Gatra, 50, 24 October 2005. http://www.gatra.com/2005-1024/artikel.php?id=89369 (accessed October 09 ${ }^{\text {th }} 2006$ ).

Boorstin, D.J., The Image: A guide to Pseudo-Events in America. New York, USA: Vintage Books, 1992.

Cashmore, E. Beckham, Cambridge. UK: Polity Press, 2004.

Debord, G. Society of the Spectacle. Translated by Ken Knabb. London: Rebel Press, 2005.

Djamaluddin, Dasman. "Mengenang Sastrawan Besar Hamka." http://buyahamka.org/bagian-sebelum-tafsir/mengenang-sastrawan-besarhamka/ (accessed November 14, 2012).

Eickelman, D.F., and J.W. Anderson, eds. New Media in the Muslim World: The Emerging Public Sphere, $2^{\text {nd }}$ ed. Bloomington: Indiana University Press, 2003.

Elegant, S. and J. Tedjasukmana, "Holy Man: Indonesia's Hottest Muslim Preachers a Slick of Piety and Prosperity." Time Asia Magazine, 11 November 2002. http:/www.time.com/time/asia/magazine/article/0,13673,501021111386977,00.html (accessed December 10 ${ }^{\text {th }} 2006$ ).

Encyclopaedia of Indonesian Figures, "K.H. Abdullah Gymnastiar: Offering Peace ad Manajemen Qalbu,” TokohIndonesia DotCom, 19 January 2003. http://www.tokohindonesia.com/ensiklopedi/a/abdullah gymnastiar/index.shtml (accessed December 10 ${ }^{\text {th }} 2006$ ).

Encyclopedia of Indonesian Figures, “K.H. Zainuddin MZ: Da'i of Reformation Star,” TokohIndonesia DotCom, 04 April 2004,

http://www.tokohindonesia.com/majalah/09/zainuddin.shtml (accessed December 10th 2006).

Geertz, C. "The Javanese Kijaji: The Changing Role of a Cultural Broker." Comparative Studies in Society and History 2 (1960): 228-249.

Golding, P. and G. Murdock. "Ideology and the Mass Media: The Question of Determination." in Ideology and Cultural Production, edited by Michele Barret, Philip Corrigan, Annette Kuhn and Janet Wolf. London: Croom Helm, 1979.

Liputan6.com, "Jeffry Al-Bukhori prefers to be called as Ustad."Liputan6.com, 3 November 2005.

http://www.liputan6.com/view/8,111846,1,0,1133557272. html (Accessed October $09^{\text {th }} 2006$ )

Newbury, M. "Celebrity Watching." American Literary History, Oxford: Oxford University Press, 2000. 
lim Halimatusa'diyah (1-16)

Roject, C. Celebrity. London, UK: Reaktion Books Ltd, 2001.

Smythe, D. The Self-Production of Society. Chicago, IL: University of Chicago Press, 1977.

Watson, C.W. "A Popular Preacher: The Significance of Aa Gymnastiar." Journal of Royal Anthropological Institute (N.S.) 11, (2005): 773-792. 